\title{
THE RADIOCARBON CHRONOLOGY OF EL MIRÓN CAVE (CANTABRIA, SPAIN): NEW DATES FOR THE INITIAL MAGDALENIAN OCCUPATIONS
}

\author{
Lawrence Guy Straus ${ }^{1,2}$ • Manuel R González Morales ${ }^{2}$
}

ABSTRACT. Three additional radiocarbon assays were run on samples from 3 levels lying below the classic $( \pm 15,500 \mathrm{BP})$ Lower Cantabrian Magdalenian horizon in the outer vestibule excavation area of El Mirón Cave in the Cantabrian Cordillera of northern Spain. Although the central tendencies of the new dates are out of stratigraphic order, they are consonant with the post-Solutrean, Initial Magdalenian period both in El Mirón and in the Cantabrian region, indicating a technological transition in preferred weaponry from foliate and shouldered points to microliths and antler sagaies between about 17,000-16,000 BP (uncalibrated), during the early part of the Oldest Dryas pollen zone. Now with $65{ }^{14} \mathrm{C}$ dates, El Mirón is one of the most thoroughly dated prehistoric sites in western Europe. The until-now poorly dated, but very distinctive Initial Cantabrian Magdalenian lithic artifact assemblages are briefly summarized.

\section{INTRODUCTION}

El Mirón Cave is located in the upper valley of the Asón River in eastern Cantabria Province in northern Spain, about $100 \mathrm{~m}$ up from the valley floor on the steep western face of a mountain in the second foothill range of the Cantabrian Cordillera, about halfway between the cities of Santander and Bilbao. The site location in the town of Ramales de la Victoria $\left(43^{\circ} 14^{\prime} 48^{\prime \prime} \mathrm{N}, 3^{\circ} 27^{\prime} 5^{\prime \prime} \mathrm{W}\right)$ is $260 \mathrm{~m}$ above present sea level, and about $20 \mathrm{~km}$ from the present shore of the Bay of Biscay (and about $25-30 \mathrm{~km}$ from the Tardiglacial shore).

In 2 earlier articles (Straus and González Morales 2003, 2007), we presented a total of 62 radiocarbon dates from occupation layers in El Mirón Cave that ranged between 41,000 BP and AD 1400: late Middle Paleolithic to late Middle Ages. The most spectacular Upper Paleolithic human occupations of this large cave pertain to the Magdalenian-Azilian cultural complex. These levels represent some $1.7-2.0 \mathrm{~m}$ of deposit in all 3 excavation areas within the large $(30 \times 7-12 \times 13 \mathrm{~m})$ cave vestibule: rear ("Corral" area), central ("Mid-Vestibule Trench"), and front ("Cabin" area). The Upper Magdalenian and Azilian (Epi-Magdalenian) periods are abundantly known and ${ }^{14} \mathrm{C}$ dated throughout the Vasco-Cantabrian region (e.g. Corchón 2005; González Sainz and Utrilla 2005; FernándezTresguerres 2007; González Sainz and González Urquijo 2007), but are poorly represented in El Mirón, suggesting sporadic, fairly short human occupations of the cave during the Last Glacial Interstadial and Younger Dryas, despite the existence of major occupations during these terminal Paleolithic times in the nearby sites of El Horno and El Valle (Straus et al. 2002). In dramatic contrast, El Mirón was a very important Lower Magdalenian site, occupied repeatedly and intensively between about 15,700-14,500 BP (uncalibrated). At this time, it was comparable to major hub residential sites located in or at the edge of the narrow coastal lowlands of central Cantabria, namely Altamira, El Juyo, and El Castillo (see Utrilla 2007). That El Mirón was part of a regional band settlement system corresponding approximately to the territory of modern Cantabria Province plus westernmost Vizcaya and easternmost Asturias, is clearly suggested by the exclusive presence in numerous sites (including El Mirón) of red deer scapulae striation-engraved with nearly identical images of ungulates (mainly red deer hinds) that are also matched by very similar engraved rupestral figures in such caves as Altamira, El Castillo, and Llonín (González Morales and Straus 2009).

\footnotetext{
${ }^{1}$ Department of Anthropology, MSC01 1040, University of New Mexico, Albuquerque, New Mexico 87131-0001, USA. Corresponding author. Email: 1straus@unm.edu.

${ }^{2}$ Instituto Internacional de Investigaciones Prehistóricas, Universidad de Cantabria, Avda.de los Castros s/n, 39005 Santander, Spain.
} 
While not unique, the long El Mirón sequence is one of very few from modern-quality excavations in which the classic Lower Magdalenian is overlain by a series of Initial Magdalenian levels. One such site is El Rascaño, a small montane cave with strong evidence of having been a specialized ibex hunting location throughout the Magdalenian and Azilian, and located in the Miera River valley, immediately west of the Asón. Its only published excavation salvaged about $2.5 \mathrm{~m}^{2}$ of remnant intact deposits in the vestibule rear and yielded a short but coherent series of ${ }^{14} \mathrm{C}$ dates, including one each for the lowest 2 Magdalenian strata, level 5: 16,435 $\pm 130 \mathrm{BP}$ and level 4: 15,990 $\pm 190 \mathrm{BP}$ (González Echegaray and Barandiarán 1981). El Rascaño lacks an underlying Solutrean component. One other recently excavated site whose stratigraphic sequence covers the Solutrean-Magdalenian sequence (but lacks a classic Lower Magdalenian) is La Riera in eastern Asturias (Straus and Clark 1986). El Mirón has all three.

The Solutrean is represented in a series of thin levels exposed in a $2-\mathrm{m}^{2}$ test pit dug below the base of a looters' crater at the rear of the vestibule, while the Initial Magdalenian is located stratigraphically above this series of levels in the adjacent Corral excavation area. Separate exposures of Initial Magdalenian occupations exist in a $1-\mathrm{m}^{2}$ test pit (P6) in the center of the Mid-Vestibule Trench (level 313) and now in another $1-\mathrm{m}^{2}$ test pit (J2) at the base of the Cabin area. These 3 exposures can be reasonably correlated geologically. In addition, there was a remnant of Initial Magdalenian sediments in a niche within the south cave wall, above the eroded surface of the steep slope of colluvialalluvial sediments leading up to the dark inner cave (see Figure 1).

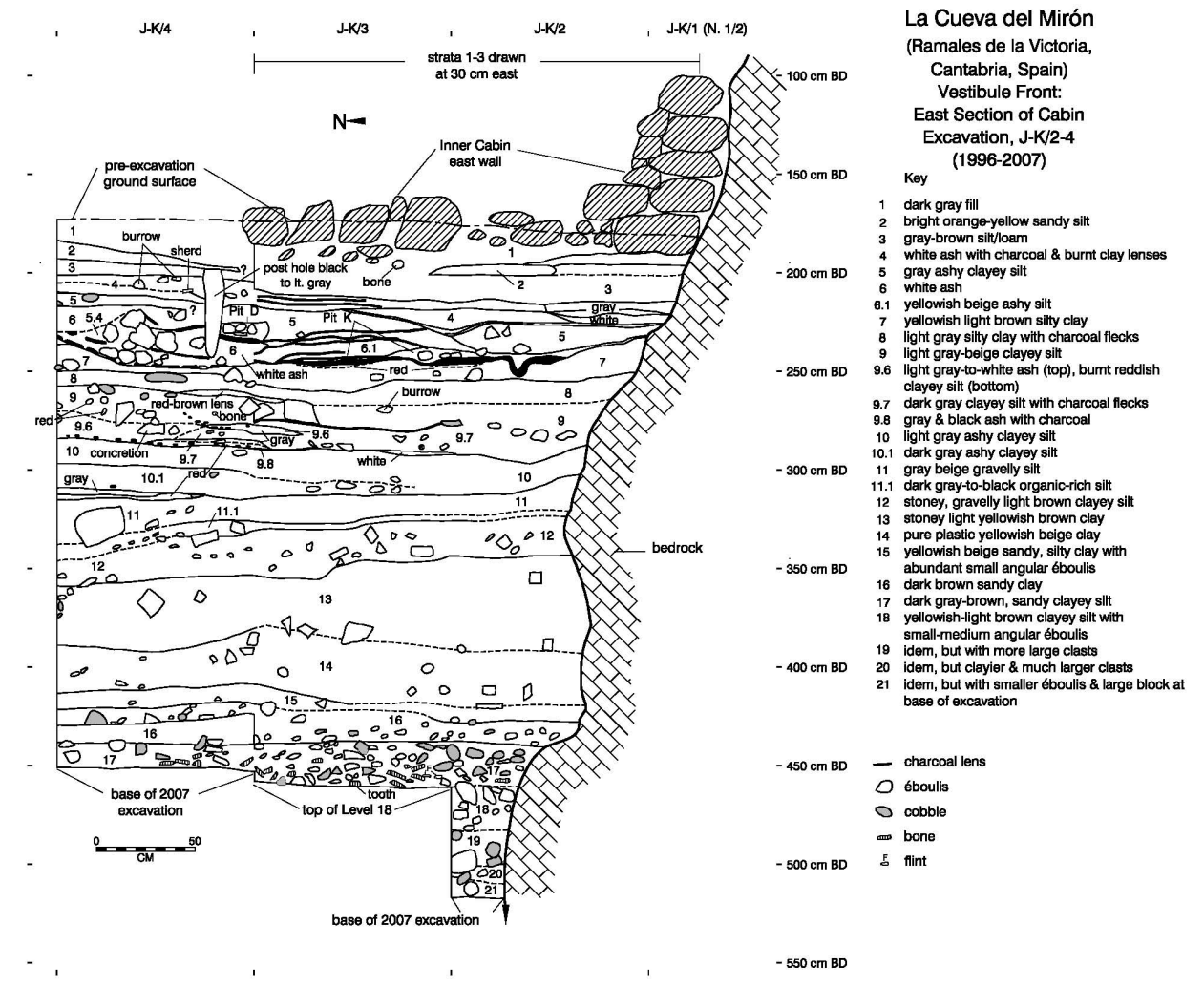

Figure 1 Stratigraphy of El Mirón Cave 


\section{THE NEW DATES}

Subsequent to discovery of the base of the massive, dark "chocolate" brown, organically and archaeologically very rich Lower Magdalenian horizon (level 17) in the Cabin, defined by a compact, lighter color surface, we opened a $1-\mathrm{m}^{2}$ test pit in square $\mathrm{J} 2$, abutting the south cave wall. Excavation led to the definition of 4 new level that had earlier been sampled by pneumatic coring. All the underlying (and intergrading) levels that could be dug in 2007 (18-21; total thickness: $\sim 60 \mathrm{~cm}$ ) are composed of yellowish-brown silts with varying proportions of clay and limestone blocks. Archaeological and faunal remains are present in all 4 levels, but in far smaller amounts than in level 17.

Levels 18 and 19 were dated with carefully selected samples of multiple, unidentifiable (but relatively large) bone fragments (mainly limb bone splinters, almost certainly red deer and/or ibex, which overwhelmingly dominate all the Magdalenian levels) from single spits in both cases. Level 21 was dated with an unusually large chunk of charcoal, identified as Juniperus sp. by Mónica Ruiz under the supervision of Dr Lydia Zapata at the Universidad del País Vasco in Vitoria/Gasteiz (Alava, Spain). The sample preparations and AMS datings were done by Dr Alexander Cherkinsky at the Center for Applied Isotope Studies of the University of Georgia. (Cherkinsky did all the other El Mirón dates when he was with Geochron Laboratories in Cambridge, Massachusetts.) The results are given in Table 1.

Table 1 AMS ${ }^{14} \mathrm{C}$ dates from the Outer Vestibule J2 test pit in El Mirón Cave.

\begin{tabular}{llllll}
\hline Level & Spit & $\begin{array}{l}\text { Date BP } \\
\pm 1 \sigma\end{array}$ & Material & Lab \# & $\begin{array}{l}\text { Calibrated date } \\
1 \sigma\end{array}$ \\
\hline 18 & 35 & $16,080 \pm 40$ & Bone collagen & UGAMS-3366r & $17,410-17,230$ \\
19 & 36 & $16,600 \pm 40$ & Bone collagen & UGAMS-3365r & $17,740-17,640$ \\
21 & 38 & $16,050 \pm 40$ & Charcoal & UGAMS-3364r & $17,370-17,180$ \\
\hline a Using CALIB 5.0 (Reimer et al. 2004; http://intcal.qub.ac.uk/calib/). &
\end{tabular}

Aside from the obvious fact that it was done on a different material than the other 2 dates, there is no ready explanation as to why the level 21 date is somewhat younger than the others. There was no void between the cave wall and the dense clayey sediments and no apparent rodent or other disturbance, although downward percolation of the charcoal lump theoretically might have occurred prehistorically. However, it was uncovered and piece-plotted in situ.

These 3 dates indicate the existence of low-intensity human occupations in this area of the cave vestibule between the classic Solutrean and Lower Magdalenian. These dates in the 17,400-17,700 cal $\mathrm{BP}$ range correspond closely to several dates for the base of the Magdalenian sequence in the vestibule rear (Corral levels 116-119.2), as well as Niche A. Although undated, the lower part of level 312 in the Mid-Vestibule Trench, bracketed by dates of 15,850 \pm 170 BP for the middle of level 312 and 17,400 $\pm 270 \mathrm{BP}$ for level 313, might also correspond to the Initial Magdalenian (Straus et al. 2008). Table 2 presents all the ${ }^{14} \mathrm{C}$ dates pertaining to the Magdalenian and Epi-Magdalenian (i.e. Azilian) technocomplex in El Mirón Cave and provides approximate correlations among levels in the various excavation areas within this large site.

\section{THE ASSOCIATED ARTIFACT ASSEMBLAGES}

Poorly known and minimally dated from recently excavated sites, the Initial Magdalenian of Cantabrian Spain has nonetheless been the subject of considerable recent debate (e.g. Bosselin and Djinjian 1999; Straus and Clark 2000; Corchón 2005; González Sainz and Utrilla 2005; Cazals and 
Table 2 El Mirón Cave Magdalenian ${ }^{14} \mathrm{C}$ chronology (1996-2007). Dates are uncalibrated BP. Numbers before the dates are levels

\begin{tabular}{|c|c|c|c|c|}
\hline \multirow{2}{*}{$\begin{array}{l}\text { Phase }^{\mathrm{a}} \\
\mathrm{AZ}\end{array}$} & \multirow[t]{2}{*}{ Vestibule Front } & $\begin{array}{l}\text { Mid-Vestibule } \\
305 \cdot 10270+50\end{array}$ & \multicolumn{2}{|c|}{ Vestibule Rear Slope \& Inner Cave } \\
\hline & & $305: 10,270 \pm 50$ & & $\begin{array}{l}\text { Breccia: } 10,390 \pm 50^{b} \\
\text { Breccia: } 10,740 \pm 40\end{array}$ \\
\hline TM/AZ & $11.1: 11,720 \pm 140$ & $306: 11,650 \pm 50$ & 102.1: $11,950 \pm 70$ & \\
\hline UP & 12: $\quad 12,970 \pm 70$ & $308: 12,350 \pm 190$ & $106: \quad 12,460 \pm 180$ & \\
\hline \multirow[t]{9}{*}{ LM } & $14: \quad 14,600 \pm 190$ & & $108: \quad 13,660 \pm 70$ & VIII: $14,620 \pm 80$ \\
\hline & $15: \quad 15,010 \pm 260$ & & 108: $\quad 13,710 \pm 70$ & \\
\hline & $15: \quad 15,220 \pm 300$ & & $108: \quad 14,710 \pm 160$ & \\
\hline & $16: \quad 15,180 \pm 100$ & & $108: \quad 14,850 \pm 60^{c}$ & \\
\hline & $17: \quad 15,470 \pm 240$ & & $110: \quad 16,130 \pm 250$ & \\
\hline & $17: \quad 15,450 \pm 160$ & & $111: \quad 16,370 \pm 190$ & \\
\hline & $17: \quad 15,700 \pm 190$ & & $111: \quad 15,530 \pm 230$ & \\
\hline & $17: \quad 15,370 \pm 80$ & $312: 15,850 \pm 170$ & $114: \quad 16,460 \pm 50$ & \\
\hline & & & 115: $\quad(13,800 \pm 840)$ & \\
\hline \multirow[t]{6}{*}{$\mathrm{IM}$} & 18: $16,080 \pm 40$ & & 116: $\quad 15,220 \pm 100$ & \\
\hline & 19: $\quad 16,600 \pm 40$ & & $116: \quad 17,400 \pm 80^{c}$ & \\
\hline & 21: $\quad 16,050 \pm 40$ & & $117: \quad 17,050 \pm 60$ & \\
\hline & & & $118: \quad 15,460 \pm 190$ & \\
\hline & & & $119: \quad 16,960 \pm 80$ & Niche: $16,600 \pm 90^{\mathrm{d}}$ \\
\hline & & $313: 17,400 \pm 270^{\mathrm{e}}$ & 119.2: $16,320 \pm 160$ & \\
\hline
\end{tabular}

Bracco 2007; Utrilla 2007). The materials from the layers underlying the classic Cantabrian Magdalenian and overlying the last Solutrean point-bearing layers in El Mirón Cave are highly relevant to the accurate characterization of this intermediate cultural phase at the beginning of the Oldest Dryas. Table 3 summarizes the chipped lithic debris found in levels 18-21 of the J2 sondage, some 3123 items total. In addition, we recovered 66 pieces of fire-cracked rock in level 18, along with a stone slab. There are a few fragments of fire-cracked rock in the other levels and 2 hammerstones in level 20. Of note is the scarcity of unretouched blades and bladelets, compared to their abundance in later Magdalenian levels. The cores are mostly flake and mixed cores, with very few purely blade or bladelet cores. The abundance of cores, chunks and microdebitage is indicative of in situ knapping.

Table 3 Lithic debris (debitage, cores and chunks) from Initial Magdalenian levels 18-21 in J2.

\begin{tabular}{lcccc}
\hline Debris class & Level 18 & Level 19 & Level 20 & Level 21 \\
\hline Microdebitage $^{\mathrm{a}}$ & 1032 & 741 & 561 & 172 \\
Flakes & 179 & 74 & 64 & 15 \\
Blades & 12 & 8 & 5 & 1 \\
Bladelets & 48 & 12 & 5 & 3 \\
Cores & 40 & 6 & 12 & 10 \\
Chunks & 66 & 27 & 17 & 6 \\
Total & $\mathbf{1 3 7 7}$ & $\mathbf{8 6 8}$ & $\mathbf{6 6 4}$ & $\mathbf{2 0 7}$ \\
\hline
\end{tabular}

${ }^{\text {a }}$ Trimming flakes and angular shatter, all $<1 \mathrm{~cm}$ in length 
Retouched stone tools (as defined by the typology of de Sonneville-Bordes and Perrot [1953]) are relatively few among the levels of the $\mathrm{J} 2$ sondage (especially the basal three). They are listed in Table 4, with a grand total of only 99 formal tools/tool edges. Because the total sample is so small, the three level 18 spits (artificial excavation layers) are combined and, in calculating percentages, levels 19-21 are also combined.

Table 4 Retouched tools from Initial Magdalenian levels 18-21 (de Sonneville-Bordes and Perrot types). ${ }^{\mathrm{a}}$

\begin{tabular}{|c|c|c|c|c|}
\hline Tool type & Level 18 & Level 19 & Level 20 & Level 21 \\
\hline 1. Simple endscraper & 1 & & & \\
\hline 2. Atypical endscraper & & 1 & 1 & 1 \\
\hline 8. Endscraper on flake & 2 & 1 & 1 & \\
\hline 13. Thick nosed endscraper & 1 & & & \\
\hline 15. Nucleiform endscraper & 2 & 1 & & \\
\hline 22. Perforator-burin & 1 & & & \\
\hline 23. Perforator & 1 & & & \\
\hline 24. Short perforator & 4 & & & \\
\hline 30. Angle burin on break & 1 & 1 & & \\
\hline 37. Burin on concave truncation & & 1 & & \\
\hline 41. Multiple mixed burin & 1 & & & \\
\hline 58. Completely backed blade & 1 & & & \\
\hline 60. Straight truncated piece & & 1 & & \\
\hline 61. Oblique truncated piece & $1(+1)$ & & & \\
\hline 65. Piece $\mathrm{w} / 1$ fully retouched edge & 2 & 1 & 2 & 1 \\
\hline 66. Piece $w / 2$ fully retouched edges & 1 & & & \\
\hline 74. Notch & $6(+1)$ & 2 & 3 & \\
\hline 75. Denticulate & $5(+2)$ & 4 & $3(+1)$ & 3 \\
\hline 76. Splintered piece (or bipolar core) & 6 & 1 & & 1 \\
\hline 77. Sidescraper & $1(+1)$ & & & \\
\hline 78. Raclette & 1 & & & \\
\hline 83. Circle segment & 1 & & & \\
\hline 85. Backed bladelet & 10 & 3 & 1 & 2 \\
\hline 86. Truncated backed bladelet & 1 & & & \\
\hline 88. Denticulated bladelet & 3 & & & \\
\hline 89. Notched bladelet & & 1 & & \\
\hline 90. Retouched bladelet & 2 & & 1 & \\
\hline Total & $55(+5)$ & 18 & $12(+1)$ & 8 \\
\hline
\end{tabular}

${ }^{\mathrm{a}}(+n)=$ additional classifiable retouched edge(s) on same blank(s) as (an)other classified tool(s)

The most striking feature of these assemblages is the relative abundance of so-called "Mousterianlike" types: notches, denticulates, and sidescrapers (26.7\% in level $18 ; 41.0 \%$ in levels $19-21)$. (In contrast, these 3 tool types make up only $12-15 \%$ of the assemblages from the various spits of El Mirón Mid-Vestibule Lower Magdalenian level 312 [Straus and González Morales 2008].) All bladelet tools combined make up an identical $26.7 \%$ of the level 18 assemblage, but only $20.5 \%$ of the combined lower level assemblages. (Bladelet tools make up 45-53\% of the level 312 spit assemblages.) Otherwise, the only tool class that is relatively well represented in the J2 sondage assemblages is endscrapers (including nucleiform endscrapers that may or may not be simply cores). Burins, perforators, and truncations are rare or absent. The only artifact said to be characteristic of the so-called Badegoulian (a.k.a. Magdalenian 0) industry is a single raclette in level 18 and there are no Solutrean points. 
A clear aspect of the tool assemblages is the fact that the Mousterian-like tools are mostly (74.2\%) made on non-flint raw materials (quartzite, limestone, mudstone, sandstone, and unidentified others). These materials are local (found in the bed load of rivers below the cave or in the alluvial fill of the inner cave itself), which makes sense given the large size and weight of these tool types, especially when compared to the small, classic Upper Paleolithic tool types, themselves almost exclusively made on flints. The average weight of the combined notches, denticulates, and sidescrapers is $23 \mathrm{gm}$. Furthermore, the cores from levels $18-21$ are overwhelmingly made of non-flints ( $87.5 \%$ of the 40 cores in level $18 ; 89.3 \%$ of the 28 in combined levels 19-21). Many of these cores are very large for a late Upper Paleolithic context (many $>100 \mathrm{gm}$, even up to $460 \mathrm{gm}$ ). In marked contrast to the overlying Lower Magdalenian assemblages, there are almost no (usually very small) cores of high-quality flint likely to have come from the coastal Upper Cretaceous sources. In contrast, the relatively few bladelet tools in levels 18-21 for which raw material type can be identified are all flint, mostly very fine-grain gray flint typical of the Barrika source. These facts tend to confirm the general impression that some Initial Magdalenian assemblages in Cantabrian Spain have an "archaic" aspect, with relatively few bladelets. In the case of El Mirón, this cannot be explained away by the physical unavailability of good-quality flints, since the site is within striking distance (40-50 km) of sources of excellent Upper Cretaceous flint, such as Barrika (western Vizcaya) and Llaranza (central Cantabria) on the present-day coastline, which were consistently exploited during the Lower, Middle, Upper, and Epi-Magdalenian occupations of the same cave, as well as in nearby El Horno Cave (Rissetto 2009).

Possible explanations in need of further exploration are that activities in El Mirón were somewhat different during the Initial Magdalenian occupations than later, and/or that human mobility was more restricted, leading to greater use of local non-flint raw materials for large, simple tools, as opposed to the smaller (more usually hafted, composite) tools and weapons made on good-quality, non-local flints that more commonly characterized the technology of later occupations of the cave. Although not yet quantified, the classified lithic assemblages from many of the other Initial Magdalenian levels in El Mirón give a similar impression: large numbers of "macroliths" on locally available non-flint raw materials. These include both large retouched tools and unretouched flakes and suggest some very different uses of the cave and/or a more restricted catchment area during the Initial Magdalenian, 17-16 kyr, than during later Magdalenian phases.

\section{ACKNOWLEDGMENTS}

Research in El Mirón Cave has been authorized since 1996 by the Gobierno de Cantabria. The 2007 field season, when the $\mathrm{J} 2$ sondage was dug, was funded by the Gobierno de Cantabria and the National Geographic Society. Igor Gutierrez Zugasti was in charge of this sondage. We thank all the 2007 participants/students from the Universities of New Mexico, Cantabria, and Zagreb (Croatia).

\section{REFERENCES}

Bosselin B, Djindjian F. 1999. Une révision de la séquence de La Riera (Asturies) et la question du Badeoulien cantabrique. Bulletin de la Société Préhistorique Française 96:153-73.

Cazals N, Bracco JP. 2007. Quelles relations de part et d'autre des Pyrénées durant le Magdalénien? In: Cazals N, González Urquijo J, Terradas X, editors. Frontières Naturelles et Frontières Culturelles dans les Pyrénées Préhistoriques. Santander: Universidad de Cantabria. p 125-42.

Corchón MS. 2005. El Magdaleniense en la Cornisa Cantábrica: nuevas investigaciones y debates actuales. In: Bicho N, editor. O Paleolítico. Actas do IV Congresso de Arqueologia Peninsular (Promontoria Monográfica 02). p 15-38.

de Sonneville-Bordes D, Perrot J. 1953. Essai d'adaptation des méthodes statistiques au Paléolithique supérieur: premiers résultats. Bulletin de la Société Préhistorique Française 50:323-31.

Fernández Tresguerres J. 2007. El final del Paleolítico en 
los espacios cantábricos: el Aziliense. In: Fano M, editor. Las Sociedades del Paleolítico en la Región Cantábrica. Bilbao: Kobie, Anejo 8. p 309-36.

González Echegaray J, Barandiarán I. 1981. El Paleolitico Superior de la Cueva del Rascaño. Santander: Centro de Investigación y Museo de Altamira, Monografías 3.

González Morales M, Straus LG. 2009. Extraordinary Early Magdalenian finds from El Mirón Cave, Cantabria (Spain). Antiquity 83(320):267-81.

González Sainz C, Utrilla P. 2005. Problemas actuales en la organización y datación del Magdaleniense de la Región Cantábrica. In: Bicho N, editor. O Paleolitico. Actas do IV Congresso de Arqueologia Peninsular (Promontoria Monográfica 02). p 39-47.

González Sainz C, González Urquijo J. 2007. El Magdaleniense reciente en la Región Cantábrica. In: Fano M, editor. Las Sociedades del Paleolítico en la Región Cantábrica. Bilbao: Kobie, Anejo 8. p 275 308.

Reimer PJ, Baillie MGL, Bard E, Bayliss A, Beck JW, Bertrand CJH, Blackwell PG, Buck CE, Burr GS, Cutler KB, Damon PE, Edwards RL, Fairbanks RG, Friedrich M, Guilderson TP, Hogg AG, Hughen KA, Kromer B, McCormac G, Manning S, Bronk Ramsey C, Reimer RW, Remmele S, Southon JR, Stuiver M, Talamo S, Taylor FW, van der Plicht J, Weyhenmeyer CE. 2004. IntCal04 terrestrial radiocarbon age calibration, 0-26 cal kyr BP. Radiocarbon 46(3):1029-58.

Rissetto J. 2009. Late Pleistocene hunter-gatherer mobility patterns and lithic exploitation in eastern Cantabria (Spain) [unpublished PhD dissertation]. Department of Anthropology, University of New Mexico.

Straus LG, Clark GA. 1986. La Riera Cave. Tempe: Anthropological Research Papers 36.

Straus LG, Clark GA. 2000. La grotte de La Riera (Asturies) et la question du Solutréen cantabrique (et ibérique). Bulletin de la Société Préhistorique Française 97:19-132.

Straus LG, González Morales M. 2003. El Mirón Cave and the ${ }^{14} \mathrm{C}$ chronology of Cantabrian Spain. Radiocarbon 45(1):41-58.

Straus LG, González Morales M. 2007. Further radiocarbon dates for the Upper Paleolithic of El Mirón Cave (Ramales de la Victoria, Cantabria, Spain). Radiocarbon 49(3):1205-14.

Straus LG, González Morales M. 2008. Addendum and correction to "Early Magdalenian variability: new evidence from El Mirón Cave, Cantabria, Spain." Journal of Field Archaeology 33(3):367-9.

Straus LG, González Morales M, Fano M, García Gelabert M. 2002. Last Glacial human settlement in eastern Cantabria. Journal of Archaeological Science 29(12): 1403-14.

Straus LG, González Morales M, Stewart E. 2008. Early Magdalenian variability: new evidence from El Mirón Cave, Cantabria, Spain. Journal of Field Archaeology 33(2):197-218, 367-9.

Utrilla P. 2007. Evolución histórica de las sociedades cantábricas durante el Tardiglacial: el Magdaleniense inicial, inferior y medio (16.500-13.000 BP). In: Fano M, editor. Las Sociedades del Paleolitico en la Región Cantábrica. Bilbao: Kobie, Anejo 8. p 243-74. 